\title{
Technologia informacyjna i przedsiębiorczość w szkoleniu kandydatów na kierowców
}

Od zarania dziejów informacja jest czynnikiem motywującym działania człowieka i motorem rozwoju cywilizacji. W prostej postaci lub przetworzona, stanowi kapitał niezbędny do sprawnego funkcjonowania każdego przedsiębiorstwa czy organizacji. Często informacja jest traktowana jak każdy inny towar, staje się tym samym przedmiotem obrotu rynkowego. W usługach edukacyjnych informacja jest elementem wiedzy nauczycieli i instruktorów. Nowe informacje instruktorzy i nauczyciele integrują z doświadczeniem, uzyskując przyrost wiedzy. Duży wzrost liczby samochodów poprawia mobilność ludzi i stwarza szansę dla usług edukacyjnych w zakresie szkolenia kandydatów na kierowców i kandydatów na instruktorów. Wzrasta również zapotrzebowanie na informację. Przed ośrodkami szkolenia kierowców stawia to nowe wyzwanie - konieczność zdobywania informacji dotyczących nowych metod szkolenia, dostosowanych do warunków współczesnego ruchu drogowego i wspomagających osiągnięcie konkurencyjnej pozycji na rynku edukacji kandydatów kierowców i kandydatów na instruktorów. Informacja i wiedza nie są tożsame, gdyż ,wiedza to zebrana, zorganizowana informacja, a sama informacja to przyrost wiedzy" (Oleński 1997, s. 17). Zmienić się musi również rola instruktora: $\mathrm{z}$ typowego praktyka mającego mgliste pojęcie o dydaktyce w dobrze przygotowanego nauczyciela nauki jazdy. Współczesny instruktor musi posiadać wiedzę i umiejętności także z zakresu technologii informacyjnej rozumianej jako ,zespół środków i narzędzi oraz z zakresu innych technologii (np. telekomunikacja), które służą posługiwaniu się informacją" (Sysło 2008). Z technologii informacyjnej (IT) instruktorzy w OSK korzystają w celu zdobycia wiedzy oraz w trakcie zajęć. Korzystanie z IT i zdobywanie wiedzy to powszechnie przyjęte kryteria oceny przedsiębiorczości (Janczewski 2005).

\section{Techniki IT jako miary przedsiębiorczości}

Techniki IT kształtują i zmieniają wszystkie obszary życia. Pod ich wpływem postęp dokonał się także w obszarze edukacji. Komputer z odpowiednim oprogramowaniem, połączony z internetem, jest podstawowym elementem procesu edukacji kandydatów na kierowców i kandydatów na instruktorów. Odpowiedni poziom wiedzy jest niezbędny nie tylko do korzystania z technik IT, ale także do prowadzenia szkolenia. Posiadanie komputera z odpowiednim oprogramowaniem, rzutnika multimedialnego lub kilku komputerów tworzących lokalną sieć stało się istotnym kryterium przedsiębiorczości każdej firmy szkoleniowej, a zatem także ośrodków szkolenia kierowców. Jeszcze niedawno do prowadzenia zajęć wystarczały wiedza, tablica i kreda, wspomagane planszami z zakresu przepisów ruchu drogowego i prostymi modelami pokazującymi budowę i działanie mechanizmów samochodu (budowa samochodu nie była tak skomplikowana jak obecnie), projektory filmowe i filmy. W części praktycznej procesu szkolenia wykorzystywano samochód szkoleniowy, plac 
manewrowy oraz ruch miejski. Obecnie, by nauczać i uczyć się przepisów ruchu drogowego oraz podstawowych czynności prowadzenia pojazdu, trzeba posiadać umiejętności w dziedzinie technik IT. Szczególnie cenna okazała się umiejętność obsługi i wykorzystania komputera i jego oprogramowania. Szybki rozwój technik IT wymusza ciągłą aktualizację sprzętu, oprogramowania i kwalifikacji (tab. 1).

Tab. 1. Porównanie wyposażenia OSK i form szkolenia

\begin{tabular}{|l|l|}
\hline \multicolumn{2}{|c|}{ Wyposażenie OSK i formy szkolenia } \\
\hline \multicolumn{1}{|c|}{ dawniej, bez technik IT } & \multicolumn{1}{|c|}{ dziś, z uwzględnieniem technik IT } \\
\hline \multicolumn{2}{|c|}{ Wyposażenie OSK } \\
\hline $\begin{array}{l}\text { tablica i kreda, książka, modele, przekroje, } \\
\text { projektor filmowy, pojazd szkoleniowy, } \\
\text { wyposażenie placu manewrowego, tradycyjne } \\
\text { metody finansowe i administracyjno-księgowe }\end{array}$ & $\begin{array}{l}\text { tablica i kreda, książka, filmy, prezentacje } \\
\text { multimedialne, symulatory on-line, trenażery, } \\
\text { programy komputerowe, pojazdy szkoleniowe, plac } \\
\text { manewrowy, wyposażenie placu manewrowego, } \\
\text { wirtualny plac manewrowy, wirtualne metody } \\
\text { finansowe i administracyjno-księgowe, rzutnik } \\
\text { multimedialny, internet, własna strona internetowa }\end{array}$ \\
\hline \multicolumn{1}{|c|}{ Formy dokształcania } \\
\hline $\begin{array}{l}\text { nauka zorganizowana formalna i nieformalna, } \\
\text { samodoskonalenie się, incydentalne uczenie się, } \\
\text { np. w kontaktach z członkami rodziny }\end{array}$ & $\begin{array}{l}\text { nauka zorganizowana formalna i nieformalna, } \\
\text { samodoskonalenie się, incydentalne uczenie się, } \\
\text { np. w kontaktach z członkami rodziny, szkolenia } \\
\text { z zakresu korzystania z technik IT }\end{array}$ \\
\hline
\end{tabular}

Źródło: opracowanie autora.

Rozwój technik IT wpływa nie tylko na wyposażenie dydaktyczne OSK, ale również na formy doskonalenia zawodowego instruktorów i kształcenia kierowców. Klienci OSK kształtują rynek szkolenia kierowców, wyposażenia dydaktycznego i administracyjno-księgowego oraz popyt na techniki IT umożliwiające wysokojakościową i tanią usługę edukacyjną. Rynek OSK można w dużym uproszczeniu podzielić na: rynek OSK pod patronatem ITS ${ }^{1}$, rynek OSK niezależnych - niepatronackich oraz rynek szkół jazdy tworzonych przez producentów pojazdów. ${ }^{2}$ Klient OSK zainteresowany jest usługą przystosowaną do swojego stanu majątkowego.

W OSK konieczna jest również wiedza z zakresu zarządzania. W dobrze zarządzanym OSK należy przewidzieć czas na doskonalenie zawodowe instruktorów, przy czym zakres szkoleń obowiązkowo powinien uwzględniać techniki IT. Dobry instruktor nie tylko uczestniczy w szkoleniach, ale także samodzielnie doskonali swoją wiedzę, np. wykorzystując zasoby internetu czy symulatory jazdy. Korzystanie z technik IT należy uznać za kryterium oceny przedsiębiorczości OSK, a miernikiem może być korzystanie z komputera, oprogramowania księgowo-administracyjnego, dydaktycznego i zasobów internetu.

Techniki IT są ważnym narzędziem zdobywania wiedzy, zwłaszcza samodoskonalenia. Szczególne istotne są zasoby internetu; właściciele małych OSK nie dysponują wolnym czasem, który mogliby przeznaczyć na doskonalenie zawodowe. Odpowiednio wykorzystane

\footnotetext{
${ }^{1} \mathrm{~W}$ celu podniesienia jakości pracy OSK, Instytut Transportu Samochodowego utworzył w 2001 r. patronat nad dobrymi, rzetelnie pracującymi OSK; więcej na stronie http://www.patronat.go.pl/

${ }^{2}$ Ten segment rynku edukacji kierowców dotyczy szkolenia kierowców mających prawo jazdy i koncentruje się na doskonaleniu techniki jazdy, np. szkoła jazdy Renault, http://www.szkolajazdyrenault.com.pl/
} 
zasoby internetu stanowią nie tylko źródło wiedzy, ale są doskonałym środkiem komunikacji i współpracy między OSK. Telefony komórkowe, znakomity środek komunikacji tradycyjnej, pozwalają także na przesyłanie wiadomości, korzystanie z internetu itp., choć niezastąpione są kontakty werbalne instruktor - kursant. Techniki IT powinny jednak stać się podstawowymi narzędziami wspomagającymi samodoskonalenie i pracę instruktora oraz każdego nauczyciela. Zdobywanie wiedzy z wykorzystaniem technik IT to zatem ważne kryterium oceny przedsiębiorczości (tab. 2).

Tab. 2. Wykorzystanie technik IT jako kryterium oceny przedsiębiorczości OSK

\begin{tabular}{|l|l|l|}
\hline $\begin{array}{c}\text { Ujęcie } \\
\text { przedsiębiorczości }\end{array}$ & $\begin{array}{c}\text { Kryterium oceny } \\
\text { przedsiębiorczości }\end{array}$ & \multicolumn{1}{c|}{$\begin{array}{c}\text { Miary kryteriów } \\
\text { przedsiębiorczości }\end{array}$} \\
\hline \multirow{2}{*}{$\begin{array}{l}\text { Oparte na naukach } \\
\text { o zarządzaniu }\end{array}$} & wykorzystanie technik IT & $\begin{array}{l}\text { korzystanie z komputera, oprogramowania } \\
\text { księgowo-administracyjnego i dydaktycznego } \\
\text { oraz zasobów internetu, korzystanie z własnej } \\
\text { strony internetowej, poczty elektronicznej, } \\
\text { trenażera, sieci komputerowej, wirtualnego } \\
\text { pojazdu }\end{array}$ \\
\cline { 2 - 3 } & zdobywanie wiedzy & $\begin{array}{l}\text { nakłady na szkolenie i doskonalenie zawodowe, } \\
\text { w tym na szkolenie z zakresu technik IT, } \\
\text { częstotliwość dokształcania }\end{array}$ \\
\hline
\end{tabular}

Źródło: opracowanie autora na podstawie: Janczewski 2005.

Z tab. 1 wynika, że wyposażenie dydaktyczne i ekonomiczne uległy poważnym zmianom. Pojawiły się narzędzia pozwalające na przeniesienie wielu zadań szkoleniowych i ekonomicznych do rzeczywistości wirtualnej, umożliwiające korzystanie z wielu technik IT.

Z tab. 2 wynika, że kryteria oceny przedsiębiorczości i ich miary nie uległy zmianie. Natomiast formy części miar ,przeniosły się” do rzeczywistości wirtualnej. Wykorzystanie aktualnych możliwości technicznych to ważne kryterium oceny przedsiębiorczości. W dobie społeczeństwa informacyjnego jej miarą są techniki IT. Wykorzystanie możliwości komputera w OSK to nie tylko wykorzystanie typowych programów finansowo-księgowych czy edukacyjnych, ale też internetu, w celu doskonalenia zawodowego oraz współpracy z innymi firmami, posiadanie własnej strony internetowej, gromadzenie informacji, prowadzenie elektronicznej ewidencji usług itp.

\section{IT w szkoleniu uczestników ruchu drogowego}

Szkolenie uczestników ruchu drogowego powinno się rozpocząć już w przedszkolu, a zakończyć szkoleniem kursowym. Każdy etap kształcenia należy kończyć obowiązkowym egzaminem warunkującym przejście do następnego etapu edukacji. Uzyskanie pozytywnego wyniku z egzaminu w czwartym etapie szkolenia powinno być warunkiem dopuszczenia do udziału w szkoleniu kursowym. Formy egzaminu powinny być zróżnicowane dla każdego etapu, lecz zakres sprawdzanej wiedzy i umiejętności musi być jednakowy na danym etapie szkolenia. Przedstawiony system wykształci nawyki bezpiecznego zachowania i poszanowania praw współuczestników ruchu. Do realizacji tak pomyślanego systemu szkolenia konieczna jest kadra $z$ dobrym przygotowaniem merytorycznym, dydaktyczno-pedagogicznym i umiejętnościami w dziedzinie technik IT (ryc. 1). 
Ryc. 1. Techniki IT w szkoleniu uczestników ruchu drogowego

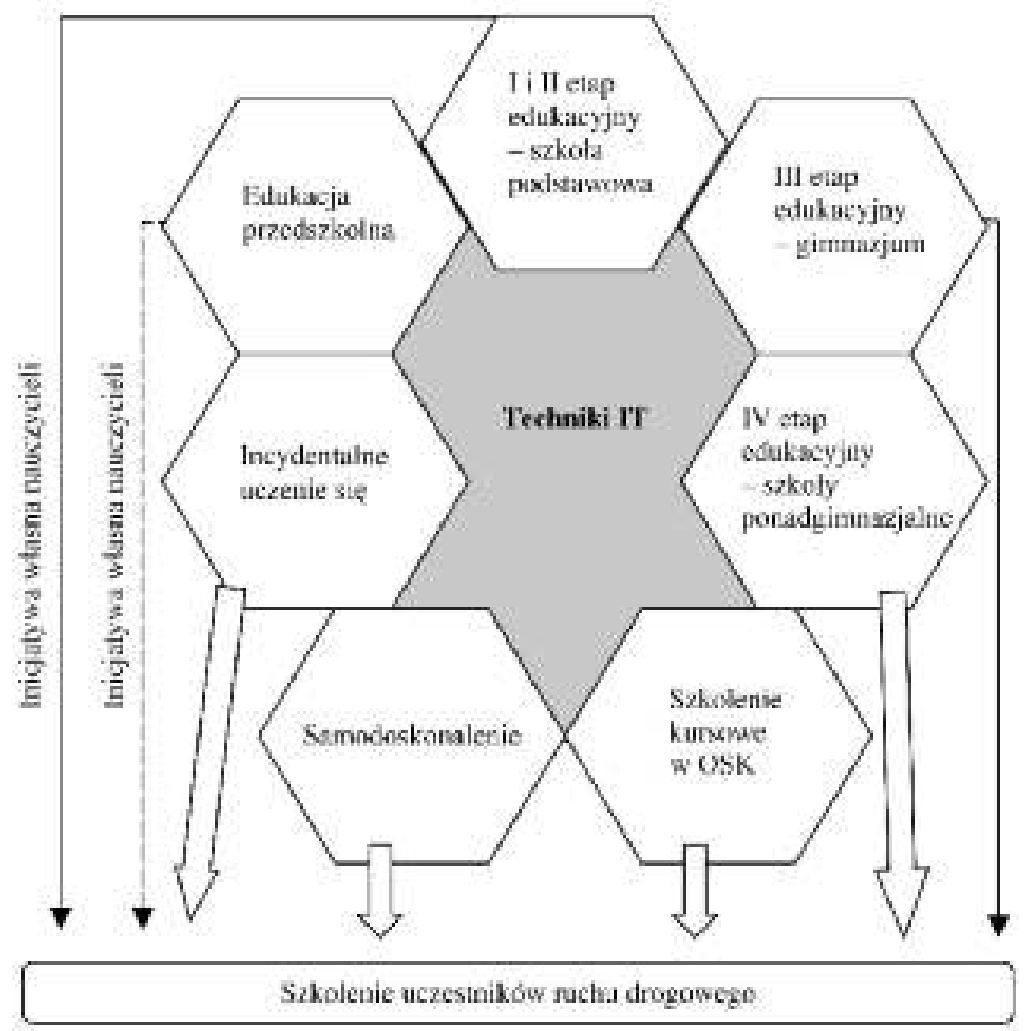

Źródło: opracowanie autora z inspiracji Przedsiębiorstwa Zastosowań Informatyki TARAN sp. z o.o, Wspomaganie zarządzania firmą komunikacyjną przy pomocy systemu Municom.premiium, 2008, Mielec,

\section{Moduł - edukacja przedszkolna}

Edukacja dzieci w zakresie wychowania komunikacyjnego powinna stanowić celową działalność społeczną, mającą na celu ukształtowanie odpowiednich motywacji etycznych, postaw społecznych oraz pożądanych zachowań w najbliższym otoczeniu. Problematyka wychowania komunikacyjnego jest wprawdzie realizowana w wielu przedszkolach od dawna, ale wynika to $\mathrm{z}$ tradycji danego środowiska oraz świadomości samych nauczycieli. ${ }^{3}$ Realizując ten obszar podstawy programowej nauczyciel przedszkola, który nie zawsze jest specjalistą w dziedzinie bezpieczeństwa ruchu drogowego, przygotowuje dzieci do bezpiecznego uczestnictwa w ruchu drogowym poprzez wykorzystanie technik IT. W celu wsparcia działań nauczycieli przedszkola w zakresie bezpieczeństwa ruchu drogowego należy:

- uzupełnić wykształcenie kadry nauczycielskiej o treści merytoryczno-dydaktyczne w zakresie bezpieczeństwa ruchu drogowego;

- uzupełnić wykształcenie kadry nauczycielskiej w zakresie wykorzystania technik IT w realizacji treści programowych wychowania przedszkolnego;

- uzupełnić programy nauczania o treści z dziedziny bezpieczeństwa ruchu drogowego.

\section{Modul - I i II etap edukacyjny, szkoła podstawowa}

Moduł ten zawiera dwa etapy: etap I - kształcenie zintegrowane oraz etap II - kształcenie w szkole podstawowej. Program nauczania dla I etapu edukacyjnego (klasy 1-3) 6-letniej szkoły podstawowej nie przewiduje bezpieczeństwa ruchu drogowego. Wyjątek stanowią szkoły specjalne dla uczniów z upośledzeniem w stopniu lekkim, dla których opracowano specjalny program wychowania komunikacyjnego. Nie uwzględniono w nim podziału na klasy,

\footnotetext{
${ }_{3}^{3}$ Przykładem może być autorski program wychowania komunikacyjnego Będę bezpiecznym kierowca, www.przedszkola.edu.pl/_publikacje07/bezpieczny_kierowca.doc
} 
grupy wiekowe itp., pozostawiając nauczycielowi swobodę doboru treści, w zależności od wiadomości i zainteresowań uczniów, inwencji nauczyciela, warunków i możliwości szkoły.

W II etapie kształcenia przewidziany jest program nauczania wychowania komunikacyjnego. Treści programu mogą być realizowane samodzielnie lub w połączeniu z programem nauczania techniki. Na jego realizację przeznaczono około 30 godzin lekcyjnych. Edukacja powinna być zakończona sprawdzianem i wręczeniem kart rowerowych. Wykorzystanie technik IT do realizacji treści programowych zależy od wiedzy, umiejętności oraz inwencji nauczyciela.

\section{Modul - III etap edukacyjny, gimnazjum}

Według B. Bogackiej-Osińskiej i E. Królickiej, autorek programu nauczania wychowania komunikacyjnego dla III etapu edukacyjnego, na realizację materiału z zakresu bezpieczeństwa ruchu drogowego wystarczy 25 godzin lekcyjnych. Treści zawarte w tym programie autorki zalecają realizować na lekcjach techniki, wychowania fizycznego, na godzinach wychowawczych oraz w ramach ścieżek prozdrowotnej i ekologicznej. Rozproszenie treści programowych na tak wiele przedmiotów nie pozwoli na ich właściwą realizację. Użycie technik IT w procesie edukacji z dziedziny bezpieczeństwa ruchu drogowego będzie znacznie utrudnione.

\section{Moduł - IV etap edukacyjny, szkoły ponadgimnazjalne}

Nauczanie przepisów ruchu drogowego na tym etapie edukacji jest ograniczone do szkół o specjalnościach samochodowych i rolniczych. Uczniowie kształcą się w zakresie bezpieczeństwa ruchu drogowego w trybie kursu dwunastomiesięcznego, którego ukończenie daje prawo przystąpienia do egzaminu państwowego. Użycie technik IT jest uzależnione od warunków i możliwości szkoły.

\section{Moduł - szkolenie kursowe}

System szkolenia kandydatów na kierowców zawarty jest w module szkolenie kursowe w OSK (ryc. 1). W skład systemu wchodzą: otoczenie, część szkoleniowa i część ekonomiczna (ryc. 2).

Ryc. 2. Technologia informacyjna w procesie szkolenia kursowego kandydatów na kierowców

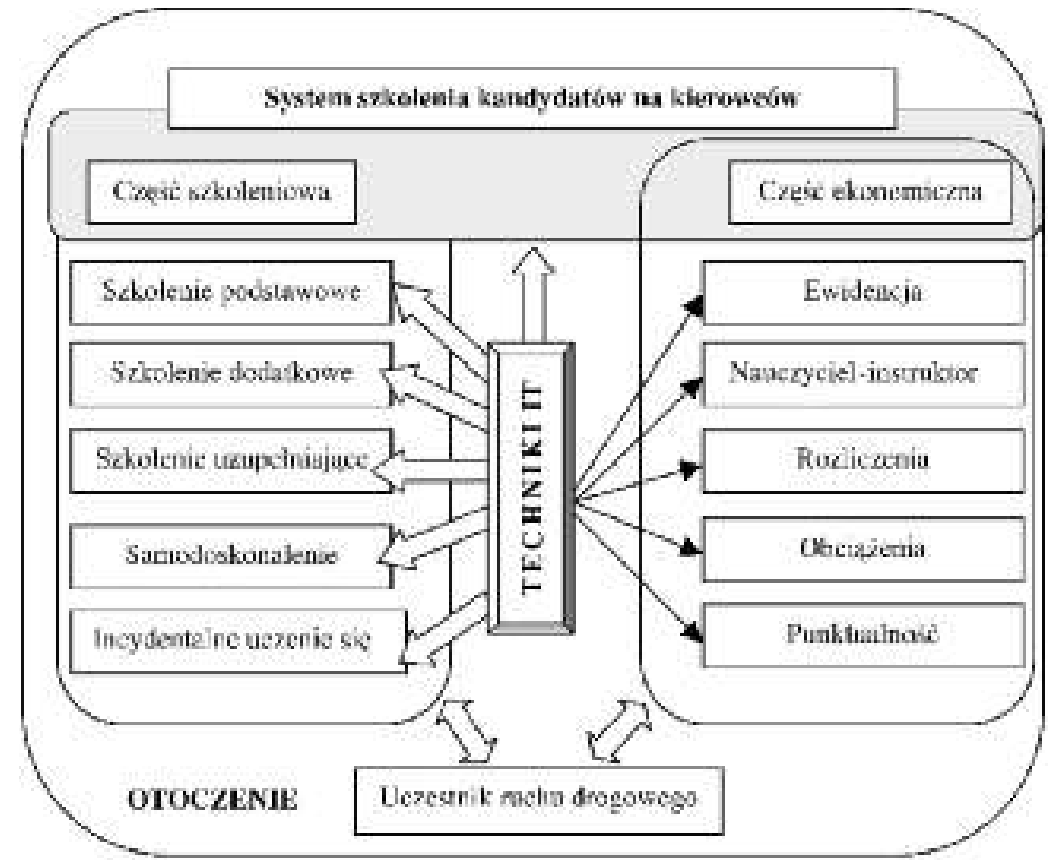

Zródło: opracowanie autora z inspiracji Przedsiębiorstwa Zastosowań Informatyki TARAN sp. z o.o, Wspomaganie zarządzania firmą komunikacyjną przy pomocy systemu Municom.premiium, 2008, Mielec. 
Otoczenie systemu składa się z podsystemu technicznego i podsystemu prawnego. W skład podsystemu technicznego wchodzą urządzenia wspierające proces szkolenia:

- lokale na biuro i salę wykładową,

- wyposażenie dydaktyczne: podręczniki, tablice, komputery, programy komputerowe itd.,

- plac manewrowy wraz z wyposażeniem,

- pojazdy szkoleniowe,

- wojewódzkie ośrodki ruchu drogowego, zwane ośrodkami egzaminowania,

- ruch drogowy.

Podsystem prawny składa się z aktów prawnych umożliwiających organizację i funkcjonowanie OSK oraz nadzór nad nimi.

Podsystem szkolenia zawiera proces szkolenia kandydatów na kierowców, składający się z części teoretycznej i części praktycznej. W procesie szkolenia są szerokie możliwości wizualizacji omawianych treści. Wykorzystuje się:

- pomoce naturalne, np. samochód szkoleniowy, ulicę, skrzyżowanie, sytuację na drodze;

- pomoce sztuczne, np. modele, plansze, makiety;

- techniki IT, np. testy komputerowe, symulacje, trenażery.

W części teoretycznej procesu szkolenia współczesny nauczyciel przepisów ruchu drogowego szeroko korzysta z narzędzi i urządzeń IT: filmów, prezentacji multimedialnych, komputera połączonego z internetem i rzutnika multimedialnego. Przykładem może być program AutoTrener - wykłady, ćwiczenia, składający się z dwóch części (ryc. 3). Część pierwsza jest przeznaczona dla instruktorów nauki jazdy prowadzących wykłady, część druga, OSK AutoTrener - ćwiczenia, jest przeznaczona do samodzielnych ćwiczeń i utrwalania wiadomości. Jest to zastosowanie technik IT w procesie nauczania i uczenia się.

Ryc. 3. Program Auto-Trener - wykłady, ćwiczenia

a) zestaw dla instruktora

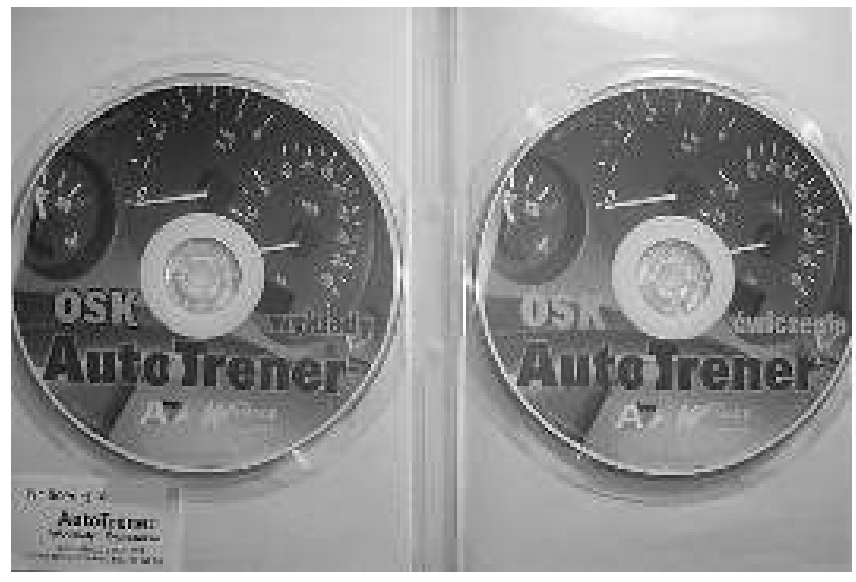

b) przykładowa strona

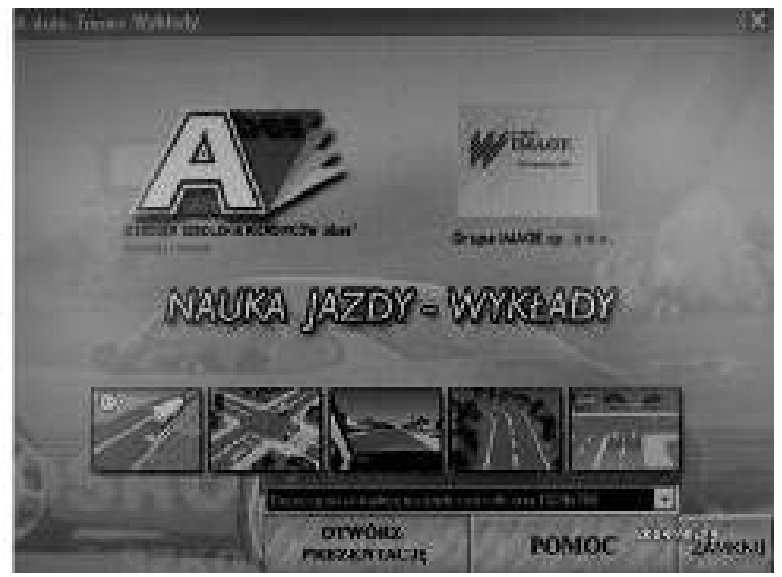

Źródło: zdjęcia autora.

Również w części praktycznej coraz szerzej wkracza IT w postaci symulatorów on-line (ryc. 4) czy trenażerów, na których kursant może w warunkach symulowanych nauczyć się wielu czynności ułatwiających mu jazdę rzeczywistą i ćwiczyć je (ryc. 5). Uzupełnieniem tych możliwości nauki oraz doskonalenia zawodowego są strony internetowe zawierające testy egzaminacyjne, symulatory i wiele innych materiałów szkoleniowych dla kursanta i instruktorów, a także egzaminatorów, np.: http://www.grupaimage.com.pl/, http://www.prawojazdy.com.pl/, http://www.kierowca.pl/. 
Ryc. 4. Symulator jazdy on-line

a) symulator na nośniku CD

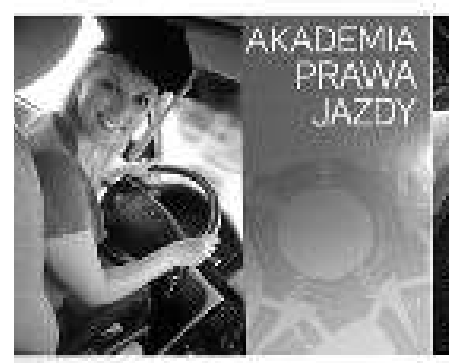

Whacrosports.

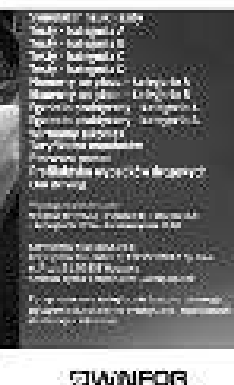

כWNFOR

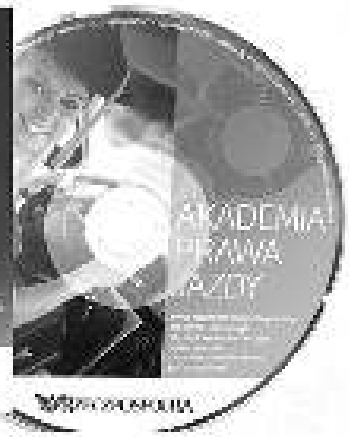

b) przykładowa strona symulatora

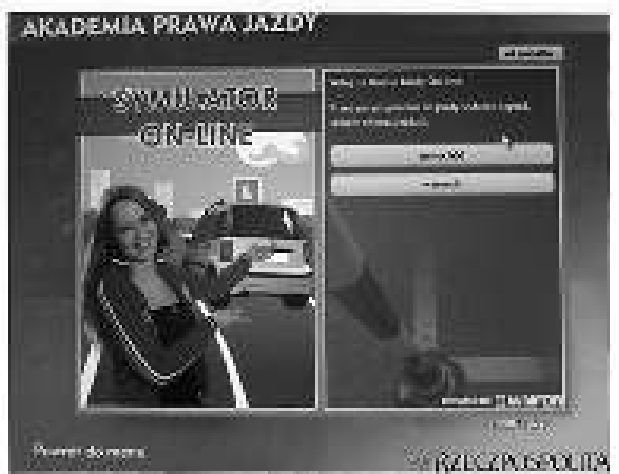

Źródło: zdjęcia autora

Ryc. 5. Stacjonarne trenażery nauki jazdy EduCar w różnych wersjach

a) pełna wersja

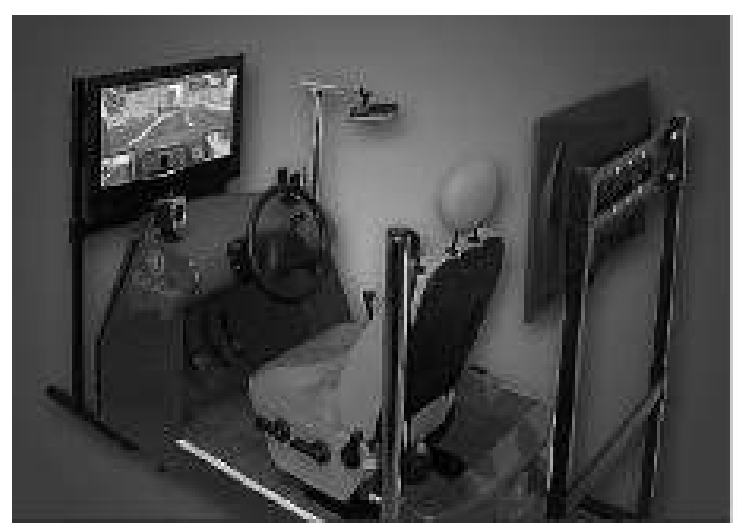

c) wersja z trzema monitorami

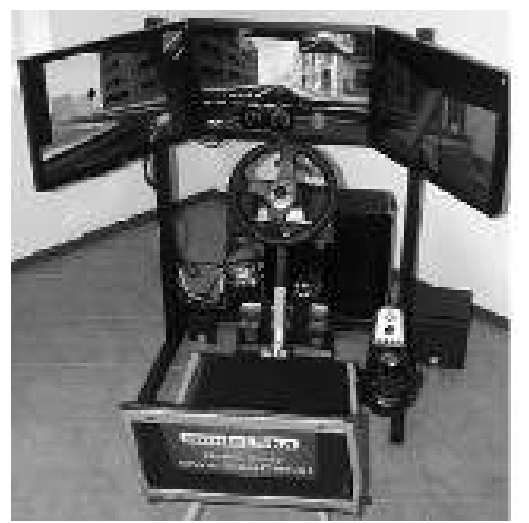

b) wersja uproszczona

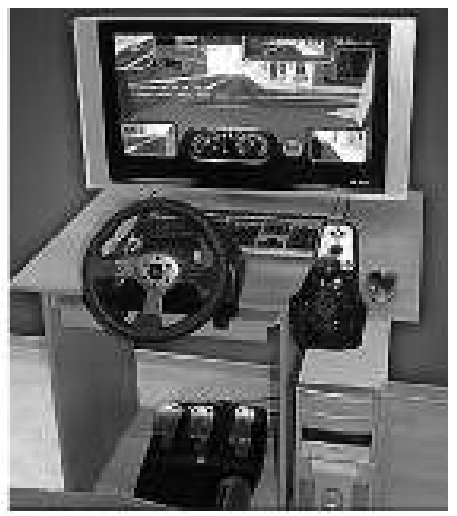

d) symulacja jazdy „po użyciu alkoholu” -ćwiczenie z użyciem trenażera i symulatora ALKOgogle

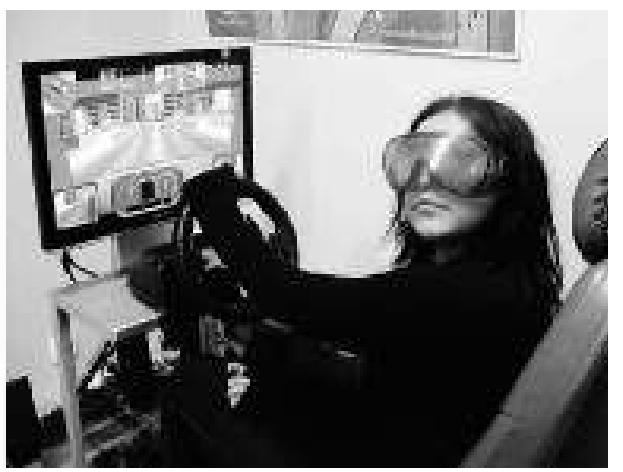

Źródło: ryc. a, b, c - http://www.educar.pl/index.htm, wrzesień 2008, ryc. d - http://gdansk.naszemiasto.pl/wydarzenia/899241.html, wrzesień 2008

\section{Modul - samodoskonalenie}

Współczesny uczestnik ruchu drogowego ma szerokie możliwości doskonalenia techniki jazdy samochodem. Do dyspozycji są techniki IT, w tym zasoby internetu, trenażery, symulatory on-line (ryc. 6). Kierowca może skorzystać z usług szkoły doskonalenia techniki jazdy i, pod okiem instruktora, ćwiczyć technikę jazdy na trenażerach i w warunkach rzeczywistych. 
Ryc. 6. Przykładowe portale internetowe umożliwiające samodoskonalenie a) testy - Winfor

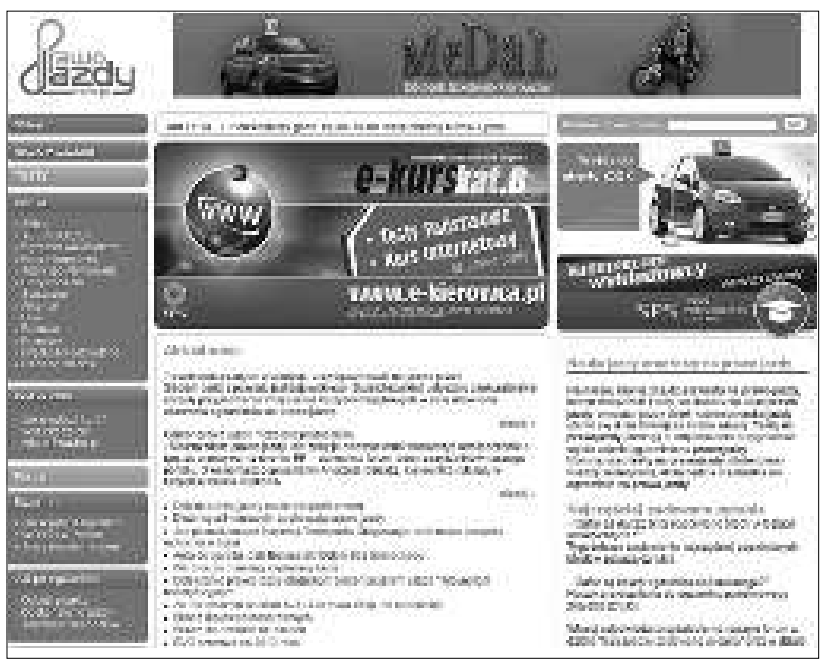

b) akty prawne - KRBRD

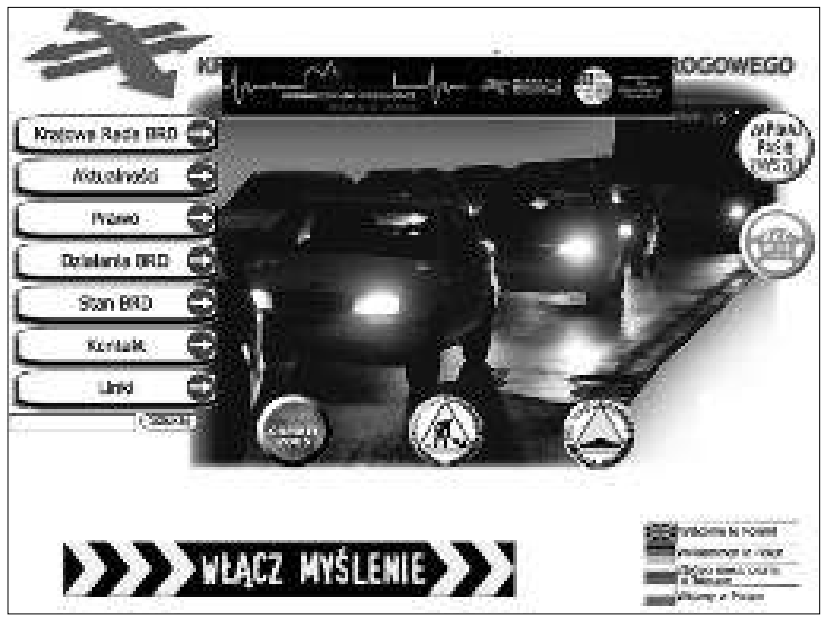

c) zakupy, nauka - grupa IMAGE

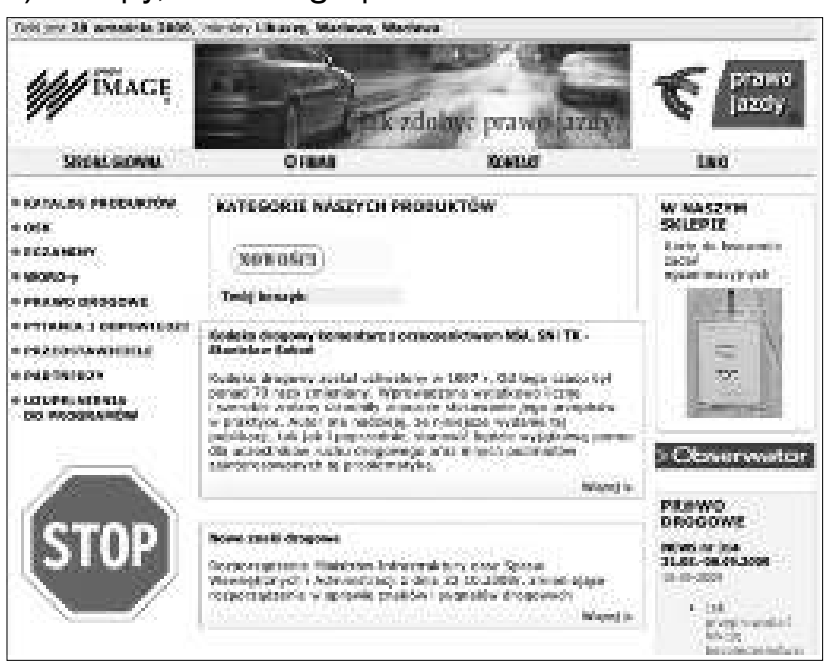

Źródło: zdjęcia autora.

\section{Modul - incydentalne uczenie się}

Incydentalne uczenie się jest na ogół niezorganizowane i nie zawsze zamierzone, np. w kontaktach z członkami rodziny, przyjaciółmi, członkami społeczności lokalnej, a także za pośrednictwem mediów (radia, TV, filmów). 


\section{Techniki IT w nowym modelu szkolenia instruktorów}

Szybkie zmiany technik IT i ich wpływ na inne dziedziny zmienia podejście kandydatów na kierowców do edukacji. Zdobyta wiedza staje się niewystarczająca i musi zostać zastąpiona przez proces ciągłego dostosowywania swojej wiedzy, umiejętności i kompetencji do zmieniających się warunków ruchu drogowego. Zmianie ulega również misja OSK, które powinny przygotowywać kursantów do ustawicznego kształcenia się przez całe życie z wykorzystaniem różnych jego form, m.in. kształcenia na odległość z wykorzystaniem internetu. Realizacja misji powinna spowodować poprawę bezpieczeństwa w ruchu drogowym. Postęp i rozwój niemal w każdej dziedzinie zawdzięcza obecne swoje tempo w dużej mierze rozwojowi technologii komputerowych i informatycznych. Techniki IT przyczyniają się do znacznego usprawnienia działania człowieka. Komputery to jednak nie tylko narzędzia wspierające inne dziedziny, w tym edukację kandydatów na kierowców. Reprezentują one sposób myślenia, który ma również duży wpływ na zmiany społeczne, w tym na edukację kandydatów na kierowców. Dlatego wykorzystanie ich możliwości jest ważnym kryterium oceny przedsiębiorczości, a zdobywana za ich pomocą wiedza to kolejne kryterium oceny przedsiębiorczości. Takie podejście do edukacji kandydatów na kierowców wiąże się ze znacznymi nakładami finansowymi, jakie muszą ponieść właściciele OSK. Wzrastają koszty szkolenia, które ponosi klient szkoły nauki jazdy. $Z$ tego powodu interesują go tylko te elementy szkolenia, które pozwolą jak najtaniej i jak najszybciej zdać egzamin na prawo jazdy. Szkoły jazdy, nastawione na szybki zysk, przyjmują sugestie klienta. W ten sposób aspekt bezpiecznego uczestnictwa w ruchu drogowym staje się niewygodnym dodatkiem do procesu szkolenia. Jest to powodem spadku poziomu wykształcenia kierowców, co objawia się ryzykownymi i niebezpiecznymi zachowaniami w ruchu drogowym. Wskazuje to na konieczność zmiany modelu szkolenia instruktorów. Nowy model powinien obejmować większą liczbę godzin zajęć z andragogiki oraz szkolenie z zakresu technik IT i ich wykorzystania W procesie szkolenia i samodoskonalenia. W nowym modelu szkolenia powinny się znaleźć zajęcia dotyczące bezpiecznych zachowań w ruchu drogowym. Ponadto, nowy model powinien wymuszać udział w okresowych szkoleniach uzupełniających oraz wyrobić nawyk ustawicznego samodoskonalenia. Nowy model powinien zawierać również zajęcia z etyki zawodu.

\section{Podsumowanie}

Techniki IT odgrywają ważną rolę w edukacji uczestników ruchu drogowego z powodu swoich olbrzymich możliwości innowacyjnych w sposobach uczenia się, metodach nauczania, środkach dydaktycznych i środowiskach edukacyjnych. Umiejętności w zakresie IT są obecnie niezbędne do aktywnego uczestnictwa w społeczeństwie i ekonomii wiedzy. IT stanowi również techniczne środowisko dla nauczania i uczenia się (np. w postaci kanału przepływu informacji i dostępu do zasobów edukacyjnych), które łatwo dostosowują się do zmian (Sysło (b) 2008, s. 2).

Wzrosła społeczna świadomość misji nauczycieli jazdy. Świadczy o tym coraz lepsze przygotowanie merytoryczne i dydaktyczne, korzystanie z porad i wiedzy psychologów, naukowców czy policji oraz umiejętność korzystania z technik IT. System egzaminowania został gruntownie „zmodernizowany” pod względem formy i zakresu i wymaga od osób egzaminowanych wiadomości i umiejętności niezbędnych do bezpiecznego prowadzenia pojazdu w rzeczywistym ruchu drogowym. Doświadczenia innych państw wskazują na ogromną rolę wczesnej edukacji dzieci i młodzieży. Często bowiem już w okresie zdobywania karty rowerowej kształtowane są nawyki bezpiecznego zachowania w ruchu drogowym. W systemie przygotowania i egzaminowania tkwią jeszcze duże rezerwy i możliwości, w tym możliwości zastosowania technologii informacyjnej. Stosowanie technik IT jest więc ważnym kryterium przedsiębiorczości OSK. 


\section{Literatura}

1. Bogacka-Osińska B., Królicka E., 2000, Program nauczania dla gimnazjum. Wychowanie komunikacyjne, numer dopuszczenia DKW-4014-129/2000, WSiP, www.wsip.com.pl/index.php/wsip_site/content/download/3405/26716/file/wychowanie_komunikacyjne_gim.pdf,

2. Chrzanowska E., Starzec K., Wojtal B, 2008, Będę bezpiecznym kierowca, Przedszkole nr 6, Tychy, program autorski, www.przedszkola.edu.pl/_publikacje07/bezpieczny_kierowca.doc

3. Janczewski J., 2005, Kryteria i miary oceny przedsiębiorczości małej firmy [w:] Z. Zioło, T. Rachwał (red.), Przedsiębiorczość a wspótczesne wyzwania cywilizacyjne, Przedsiębiorczość - Edukacja nr 1, Wydawnictwo „MiWa”, Akademia Pedagogiczna im. Komisji Edukacji Narodowej w Krakowie, Kraków.

4. Oleński J., 1997, Standardy informacyjne w gospodarce, Wydawnictwa Uniwersytetu Warszawskiego, Warszawa.

5. Sysło M.M. (a) 2008, Szkolny leksykon informatyczny, http://www.wsipnet.pl/cgi-bin/ sli/sas.cgi? $\mathrm{r}=1045 \& \mathrm{p}=50 \mathrm{c} 9.1 \&$ version.typ $=2 \& \mathrm{f}=\mathrm{DOC}$

6. Sysło M. M. (b) 2008, Szkoła jako instytucja ustawicznego kształcenia $i$ zwiazana z tym rola technologii informacyjnej, http://www.wsipnet.pl/dane/pliki/kluby/8//LLL\%20-\%20Krakow.pdf

7. Wspomaganie zarzadzania firma komunikacyjna przy pomocy systemu Municom.premium, materiały reklamowe, 2008, Przedsiębiorstwo Zastosowań Informatyki TARAN sp. z o.o., Mielec

\section{Information Technology and Enterprise in the Training Candidates for Driving Instructors}

The article discusses the role of enterprise and Information technology in the training candidates for driving instructors.

The necessary of using the Information technology during the training was pointed out. Also, the influence of Information Technologies on the basic teaching methods, like principle of visual method and connections between theories and practice, was quoted.

It underlines the role of instructor in process of new drivers' education. The necessity of creation a new teaching model was pointed out.

The article also emphasizes the importance of enterprise and information technology in the self-training for candidates for drivers and instructors; it also shows the drivers and instructors as representatives of information society. 